\title{
The Hansen Centenary
}

\section{Hansen, Bergen and Leprosy*}

Nearly 700 years ago, the first St Jörgen Hospital was built in Bergen; its purpose was to house those afflicted by leprosy. The disease was then rife in Western Norway, having been brought from Britain (according to some) by the returning Vikings. At that time, leprosy was probably very prevalent in Ireland and also in England. The Crusaders also brought back leprosy with them from the lands of the Eastern Mediterranean. Bergen and its neighbourhood becam

leprosy in Norway. According to some accounts, the prevalence reached a record of 1 in 50 suffering from the disease.

The situation became alarming, and it was decided in 1838 to build two more leprosy hospitals in Bergen, in addition to one at Molde and one at Trondheim. More was happening, however, in the world of leprosy than building hospitals for the segregation of leprosy patients and the encouragement of indigent patients to cease "boarding out" and to enter hospital. In that same year, 1838, Dr Danielssen began his life's work for leprosy in Bergen, and only nine years later published, with the collaboration of Boeck, his monumental clinical work on leprosy, Om spedalsked, which was to revolutionize medical thinking about the disease.

On 20 July, 1841, the unnoticed birth of G. H. Armauer Hansen into a humble Norwegian home also marked the end of an era and the beginning of a new one. Twenty-seven years later, after working as a doctor in the Lofoten Islands and studying in Austria, young Hansen returned to Bergen and began work at the St Jörgen Hospital. It was here that he pursued his hard course of observation and study, the sympathetic interrogation of leprosy patients and their relatives, and the painstaking pathological examinations that led him to his discovery of Mycobacterium leprae and his identification of the bacillus as a necessary and unique factor in the causation of leprosy.

Bergen as a city was no longer ashamed of its leprosy problem. It became proud that one of its young sons, a scientist only 31 years of age, was unravelling some of the tangled skeins of transmission and infectivity in his little laboratory in the St Jörgen's Hospital. Bergen became the Mecca of investigative scientists, of bacteriologists, and of laboratory workers using the new techniques and the new aniline stains being made available.

In 1909 the Second International Leprosy Congress was held in Bergen under the presidency of Hansen himself. Internationally renowned scientists paid tribute to him. His researches have a decidedly modern ring about them, as he skilfully presided over the Congress and helped to word the resolutions passed: leprosy is contagious, they said, and the portal of entry is most likely the nose. Man alone is

\footnotetext{
* Notes of an address given by Dr S. G. Browne in the Häkonshallen, Bergen, Norway, on the occasion of the Centenary commemorative celebrations, on 28 February, 1973.
} 
the victim of this disease; leprosy is not hereditary, though there were some awkward facts that still did not seem to conform completely to the theory of contagion; and-one thing they all-agreed on-leprosy is most difficult, if not impossible, to cure.

King llaakon travelled from (the then) Christiania to attend this Second Congress. Railways, museums and tramcars gave free passes to the participants. The whole town of Bergen was beflagged and gay with bunting for the occasion. Why should Bergen thus be favoured to take to its heart not only Hansen himself, but the whole Congress? Part of the answer lies with Hansen, and what he had done. He was a more significant pioneer, a deeper thinker, than most of his contemporaries realized. He learned from the past, but was not enslaved by any predetermined theory or way of looking at a socio-clinical entity. He learned from many workers in many lands, and tasted of the cosmopolitanism of true medicine. He had made for himself a sound basis of pathological observations. Thus, he submitted his findings to the severe and necessary arbitrament of observable fact and scientific demonstration.

He did not shrink from espousing an unpopular cause, or from facing criticisms alike from those who were bound by tradition and those whose feelings were swayed by emotionalism. He listened to ordinary folk-leprosy's victims - with an open and enquiring mind, trying to elucidate the pattern of spread of the disease. He was, in the days when the term was unknown, already an epidemiologist at heart. He never forgot the terrible end-results of progressive leprosy, and the social consequences of deformity and blindness and peripheral ulcerations. The fascination of the disease overcame his early revulsion and spurred him into renewed intense study of pathology, of pathogenesis, and of microbiology when these branches of science were still in their infancy. He profited from researches in related fields-in staining techniques and microscopical investigations of all kinds.

He was, moreover, understandably cautious in his oral and published statements, not claiming too much and not going beyond logical deductions of his observed findings. Some would suggest that he was a trifle too diffident, and could have claimed more than he did.

He epitomized much that remains enigmatic in leprosy investigation. He and his father-in-law, Danielssen, studied the same material, and came to diametrically opposed conclusions. The Royal College of Physicians of London had categorically stated in 1869 that leprosy was a hereditary disease, and then shortly afterwards Father Damien contracted it in Molokai-and he had an impeccable history of Belgian peasantry going back for many years. That is Hansen-a man with a vision, with an infinite capacity for hard work, and with a persistently enquiring mind.

Today, Hansen's example challenges young Norwegian scientists to reach out, both geographically and academically, to explore new areas of beckoning research, to employ all the new investigative techniques and tools as they venture into the realms of immunology, electron microscopy, biochemistry and the rest. Not only in Bergen, in the Gade Institute, but away out in Addis Ababa in the Armauer Hansen Research Institute there is good work waiting to be done in the pursuit of knowledge, the relief of suffering, and the enhancement of human happiness.

Hansen thus challenges today's youth in Norway and elsewhere. 


\section{Commemorating Hansen}

On 28 February, 1873, G. H. Armauer Hansen concluded that the small brown staff-like bodies he had been seeing frequently during the previous four years in material obtained from nodular lesions in patients suffering from certain kinds of leprosy, must be causally connected with the disease. It is true that the anthrax bacillus had been recognized a quarter of a century earlier, and the spirillum of recurrent fever had been identified before Hansen published his findings, yet to him belongs the honour of demonstrating the bacillary cause of a specifically human disease, leprosy.

One hundred years later, in the Botanic Gardens in Bergen, Norway, a group of scientists, leprologists, national and civic dignitaries and members of the Hansen family gathered around the bust of G. H. Armauer Hansen to commemorate this epoch-making discovery. Professor Th. M. Vogelsang, the Norwegian medical historian, spoke of Hansen the man, the scientist and the epidemiologist, before laying a wreath at the foot of the pedestal bearing the bust. Dr S. G. Browne, representing the International Leprosy Association-the inheritor of the scientific legacy and the social concern of Hansen-referred to the repercussions of Hansen's discovery on the world of leprosy sufferers. Hansen's seminal influence was to be seen today in such institutions as the Royal Society of Tropical Medicine and Hygiene, London, and in the increasing emphasis placed by such voluntary agencies as The Leprosy Mission, LEPRA, and the Member-Organizations of ELEP on the treatment and control of leprosy. Dr Browne then placed a wreath from the International Leprosy Association at the foot of Hansen's memorial bust.

Soon after this ceremony, held in the open air in a Bergen cradled in snow-clad hills, a representative audience filled the historic Häkonshallen (rebuilt after being totally destroyed in World War II), where His Majesty King Olav V, Royal Patron of the Tenth International Leprosy Congress to be held in Bergen in August, 1973, graced the commemorative celebrations. After a prize-winning male-voice choir had given a superb rendering of a lament and tribute in Norwegian specially written for the occasion of Hansen's funeral service on 17 February, 1912, and sung to an air by Edvard Grieg, Professor Erik Waaler welcomed King Olav, together with representatives of the City of Bergen, the diplomatic corps, and the worlds of art, science, and learning. The Mayor of Bergen (Professor Ole Myrroll) paid a fitting tribute to the discovery by one of Bergen's most illustrious sons of the bacterial cause of leprosy, and Dr S. G. Browne followed with a specch that assessed the significance of Bergen in the national and international history of leprosy. Professor Morten Harboe gave a masterly disquisition based on a study of the relevant original texts-including all Hansen's early scientific papers-and emphasized the quality of the scientific observations that led to, and stemmed from, the identification of Mycobacterium leprae as the causative agent of leprosy.

At a luncheon given by the City of Bergen, H.M. King Olav-the guest of honour-spoke of Armauer Hansen as a great son of Bergen and citizen of Norway. Professor Erik Waaler presented the King with a gold and a silver medal specially struck for the centenary commemorations. One side depicts Armauer Hansen and his microscope, and the obverse shows St Jörgen's Leprosy Hospital, Bergen. (The medals are now on sale.) Special stamps were also issued on 28 February to mark the occasion. 
The Second International Leprosy Congress was held in Bergen in 1909, Hansen himself presiding. The Tenth Congress will provide a fitting forum for presenting and discussing aspects of advances in leprosy research that reflect not only the perennial problems debated in 1909-such as transmission and treatment and the influence of hereditary factors-but also the tremendous progress made of recent years by the exploitation of modern investigative techniques. 